\title{
Rethinking the Origins and Purpose of Religion: Jesus, Constantine, and the Containment of Global Revolution
}

\author{
By Mike Sosteric
}

\begin{abstract}
For sociologists, Jesus Christ and the associated Catholic Church are generally seen are regressive, conservative, and authoritarian. For this reason, Sociologists avoid reading the Bible as a textual research source. Overcoming sociological resistance, however and examining the Christian New Testament reveals a story much different than expected. While the Church may certainly be conservative, regressive, authoritarian, even predatorial, Jesus Christ and his apostles were not. Exegesis of Christian gospels reveals not a gentle shepherd of sheeple, but a revolutionary Christ that is neither conservative, gentle, nor passive - an impassioned and committed revolutionary set on progressive social change and fundamental revision of elite power structures.
\end{abstract}

Keywords: Religion, Christianity, Jesus Christ, Critical theory, Narrative analysis.

"It is time to put an end to the distorted picture of the Bible as a pious church-andfamily book that teaches submissive obedience, other-worldliness, mortification of the flesh, and indifference to social betterment. To wrest the most powerful tool of progress from the forces of reaction is simply a matter of decency and honesty. This most revolutionary of all documents must no longer be used for the purposes of social oppression. It is time to take the document which set the pattern for all later revolutions back." Eric Gutkind - The Biblical Call to Revolt

\section{Rethinking the Origins and Purpose of Religion}

I was born a Catholic, dutifully went to Church every Sunday, and even spent time as an altar boy. However, I rejected the faith at an early age, twice in fact. I rejected it once when I was eight or ten, and once again when I entered university. The first time I rejected it was because I couldn't abide the mean-spirited hypocrisy of the people (parents, my teachers in Catholic school, neighbours) who professed a Christian faith but then were violent and mean to others. I didn't reject all human spirituality at that point, however. Driven by a powerful need to know (Sosteric and Ratkovic 2018), and presuming that ultimately there must be something to see, I spent my adolescent years fishing about in the New Age bookstore that had popped up in my hometown in the early 1980s, but without much spiritual satisfaction. None of it made any sense to me. I kept hope alive, but years later, while doing a Sociology degree, I read the famous words of Karl Marx who said: "religion is the opiate of the masses" (Marx 1978). I scanned back at my childhood

*Associate Professor, Athabasca University, Canada. 
experience of religion, my meandering dissatisfaction with New Age teachings, all the things I had learned in sociology, and a couple of those Python movies, and I had to agree. Religion was a collective human delusion. It was elite machination designed to control the population of the planet period (Berger 1969) Further examination would be a waste of my time, I felt, and so I rejected it again, this time permanently.

Since that time, as a sociologist, I have not felt comfortable talking about spirituality, especially when in the company of other sociologists, because sociologists generally dismiss religion and human spirituality as a topic "dripping with reactionary supernaturalism" and "beyond the pale at self-respecting faculty parties" (Berger 1999: 4). Individual paths of rejection may be different than mine, but most (if not all), eventually reject it. Some sociologists do look at human spirituality, but it is always with an institutional focus. Those that look, look at religious institutions, but leave out any consideration of spiritual experience (Sosteric 2017). They talk about churches, sects, and sometimes cults (Wallis 1976), and are generally very critical about them. They (we) see the manipulative aspects of organized religion (Berger 1969). We see it is an opiated delusion (Marx 1978), and an ideological tool of the elites (Weber 1904). The kinder amongst us give religion some credit for providing social solidarity and community (Durkheim 1965). However, beyond this institutional focus, we do not go. We don't take human spirituality, and in particular spiritual experience, seriously. In fact, we pretty much ignore. If we are being honest, we expect all aspects of "reactionary supernaturalism" spirituality to eventually die in a modernizing, secularist, rush (Bruce 2002, Chaves 1994).

Given this rejection of religion and spiritual experience, it should come as no surprise that sociologists don't spend much time reading the Bible, even though they do examine the Church, and even though it is the textual source of one of the world's biggest religions. Why should they? If religion is "reactionary supernaturalism," then the Bible is the source of all that, at least for Christianity. The assumption of most sociologists, I think it is fair to say, is that the Bible is chock full of elite lies and collective self-deception. Within the sociological community, the Bible has the status of a vomitous soaked rag. We keep it as far away from us as possible.

This rejection seems to be written into the DNA of the discipline. Auguste Comte (1798 - 1857), one of the heavyweight fathers of sociology, said societies passed through three stages, a theological stage where humans rely on supernatural explanations, a metaphysical stage where humans replace superstitions with abstract forces governing human behaviour, and a final positive stage where humans replaced their superstitions with logical, positive thought. For Comte, and for many sociologists, these stages represent an evolution from a dark and primitive past to a future of bright scientific light-filled rationality. The message is clear: as we evolve, religion dies away. Sociologists even formalized their expectations into secularization theory (Berger 1968, Dobbelaere 2002, Bruce 2002, Chaves 1994). Secularization theory states clearly the sociological prediction that religion and human spirituality will eventually be replaced by secular, rational, "positive" thought. 
For a long time, I bought the party line. I didn't have any interest in religion at all, I didn't consider "spiritual experience" to be anything more than individual or collective self-delusion, and like Saul on the road to Damascus, I wasn't shy about my disgust and disdain for it. Of course, I wouldn't touch the Bible with a ten-foot disinfectant pole. I hadn't read the bible when I was a child because the priests always fed it to me in little spoonfuls, and I certainly wasn't going to read it after Marx. Then one day after having experienced "mystical" experiences (I call these connection experiences) (Sosteric 2018a) powerful enough to cause me to call into question my Marxist atheism, I reversed my antagonistic position and became quite interested in human spirituality and spiritual experience (Sosteric 2014, 2018b, 2019b, 2018c, 2018d), not as some stupid human delusion likely to die away, but as a core and important aspect of human experience. In all that effort and research, however, I stilled stayed far away from the Christian Bible, believing that even though there might be something in human spirituality, there was certainly nothing in the Bible itself.

I changed my tune on the Bible, quite dramatically, however, after discovering a fellow by the name of Bartolome de las Casas. Las Casas was a brutal Spanish colonizer who literally burned slaves alive to promote the colonial agenda. However, after reading a passage from the Christian Bible during a Sunday service, like a logic switch, he flipped. One day he was burning and mutilating the natives of Hispaniola and the next he had taken a sudden "turn to the left" and was campaigning to end exploitation (Sosteric 2018c). It was a remarkable transformation, yet it took a while for me to process the full significance of Las Casas's "conversion" (i.e. turn to the left), and the fact that it happened after he read the Bible. As I did process the significance of that, a question formed. What was it about the Bible that had caused his dramatic shift? After an unproductive search for previous research that might provide for me a focused view (notice I was still avoiding the Bible), I eventually decided to pick it up and actually read it for myself. I skipped the Old Testament and started with the four gospels, Mathew, Mark, Luke, and John. These gospels, written sometime in the first century after Christ's death, ostensibly contain the last few years of this famous messiah's life.

So, what did I find when I picked up the bible ${ }^{1}$ I can tell you, it was exactly the opposite of what I had expected. As a recovering Catholic who had rejected Christianity as hypocrisy and self-delusion, as a sociologist who had absorbed the revelatory reasoning of Karl Marx, even as someone who had had a few connection experiences, I expected to find nothing but drivel. As a child raised in a

\footnotetext{
${ }^{1}$ There are many versions of the Christian Bible in existence. The Bible Gateway website (https://www.biblegateway.com) lists 60 English versions. Not all of these represent significant textual forks, but some do. Given the soteriological cornucopia a question must arise, which bible did I choose for this exegesis? I chose the New International Version by the International Bible Society, a "completely original translation of the Bible developed by more than one hundred scholars working from the best available Hebrew, Aramaic, and Greek texts" ("New International Version (NIV) - Version Information - BibleGateway.Com" 2019). The methodology used to translate the original texts was impressive. For more see the Biblica website at https://www.biblica. com/niv-bible/.
} 
Catholic family and indoctrinated by our Church's priestly pulpit pundits, I expected to find a gentle Shepard tending to a passive flock. As a Sociologist who'd read Marx, Weber, and Berger, I expected to find elite ideology and mind control. As a budding mystic, i.e. as someone who induces Connection with the express purpose of exploring, understanding, and writing about spiritual things, I wasn't expecting anything but empty words. What I found was much different than that.

Upon exegesis, I learned that Jesus was a grassroots kind of guy. He was modest and egalitarian (John 15: 12-15). He hung out with the lowest of the low, i.e. adulterers, prostitutes, sinners (Mark 2: 15), and tax collectors (Mathew: 9: 1012). He showed respect to society's detritus by humbly washing their feet (John 13: 4-8), said we should love each other (Mathew 22: 34-40), and otherwise treated most of the men and women around him as equals and with respect. Interestingly, he had much more respect for women than the typical citizen of his day. He treated them as his equals (John 4: 27) and even suggested that women should not be treated as property. In one bible scene, Sadducees (local priestly elites) asked Jesus which of seven brothers a woman, who had been married to them all, ${ }^{2}$ would "belong" to "in heaven" after they were all dead. In a remarkably progressive pronouncement, Jesus intimates marriage was a property thing and suggests that in fact, you shouldn't treat anybody like property. "You are in error because... at the resurrection people will neither marry nor be given in marriage" (Mathew 22: 2330)

When I read the above bible story, I was quite surprised. As a child, the priest drilled into me the sacrosanct and sacred nature of marriage and the patriarchal nature of power. The man was the king of his home throne, they would say. Because of the things they'd taught me about God, the Church, Adam, and after Sociology opened my eyes to the true nature of religion, I had always assumed that patriarchy was a bible thing; but then I read the Bible and found Jesus saying we shouldn't treat each other, and in particular women, as property. I wasn't expecting that at all, and I didn't expect what came next. To make a longer story short, the New Testament, and in particular the Gospels and the Acts, painted a picture of Jesus, and the Christian $\mathrm{Way}^{3}$ as an anti-elite, anti-authoritarian, progressive political revolutionary who was impatient with people's ignorance and who got himself in serious trouble with the ruling class of his day because he a) had no respect for their authority, b) was undermining their power and privilege, and c) was threatening a socialist revolution.

Consider, he ignored the rules and authority of the ruling class by repeatedly working (Mathew 12: 1-2) and healing (Mathew 12: 9-12) on the Sabbath, even after being repeatedly instructed not to do so (John 5: 16-17).

\footnotetext{
${ }^{2}$ Take a moment to wrap your head around that for a moment. Married to all seven brothers?! This woman was family property, not an independent human being.

${ }^{3}$ Jesus's teachings are referred, subsequent to his assassination, as "The Way" several times in the Bible. See Acts 9: 1-3; Acts 19:9, Acts 24: 14.
} 
He aggressively and violently kicked people out of the sacred spaces (i.e. temples) for what he considered blasphemous commercial activity (John 2:13-17).

When the elites and higher-level authority figures questioned him about his activities, he told them they had no authority over him (John 5: 16-27).

$\mathrm{He}$ made fun of the rich and powerful, calling into question their inability to connect, and comparing them, derisively, to fat camels trying to get through tiny needles (Mark 10: 25).

He called the "priests and lawmakers" hypocrites to their faces (Mathew 23: 1-7), made them look like idiot fools (John 8:1-11), said "tax collectors and... prostitutes" were better (Mathew 21: 28-31), accused them of being blind and filled with $\sin$ (John 9: 38-41), ${ }^{4}$ and generally (and very publicly) brought out their guilt and their shame. In one particularly interesting scene, the "Pharisees and teachers of the law" ask Jesus why he and his disciples were "breaking the tradition of the elders" by not washing their hands before they eat (Mathew 15: 1-2). ${ }^{5}$ Annoyed by this question, perhaps because he was tired of hearing from them and just wanted to sit peacefully and eat, Jesus looks up and snaps back.

"Why do you break the command of God for the sake of your tradition," he says.

"You hypocrites!' he exclaims.

"Isaiah was right," Jesus says with disgust.

"These people," he says, sneering at and referring to the priests, "honour me with their lips, but their hearts are far from me."

"They worship in vain; their teachings are merely human rules" (Mathew 15: 8-9).

"Listen and understand," Jesus says, "What goes into someone's mouth does not defile them, but what comes out of their mouth, that is what defiles them" (Mathew 15: 10-13).

These people, he says, these Pharisees and lawmakers, these pretenders to spiritual connection, are hypocrites.

"Be careful" (Mathew 16: 6) of them, he says elsewhere. "Be on Guard against ... [their]... teaching[s]" (Mathew 16: 6)." "They are liars and fools who don't deserve entrance into the Kingdom (Mathew 22: 1-10).

As a sociologist, recovering Catholic, and mystic, reading the above story was definitely a WTF moment for me. When I picked up the Bible, I had expected to find a passive shepherd of sheeple. As it turns out, however, Jesus was no patient sheepherder. He was nice to the common people, especially the downtrodden, but not fond of the elites at all. He could even, much to my surprise, be impatient with his friends and followers. When Peter, his disciple, asks him to explain something he did not understand, he snaps back at him and wonders out loud, "Are you still so dull?" (Mathew 15: 16-20). Jesus displayed similar impatience with ignorance when he tried to teach Nicodemus, who was a member of the Israeli elite, a Pharisee, and "teacher of the people." At one point, Nicodemus expresses

\footnotetext{
${ }^{4}$ Mathew 21 through 22, is one parable after another (the Parable of the Two Sons, the Parable of the Tenants, and the Parable of the Wedding Banquet) slamming and shaming the elite.

${ }^{5} \mathrm{We}$ will ignore, because it is irrelevant, what this says about the hygiene of Jesus and his apostles and instead focus on their anti-authoritarian response.
} 
confusion about what Jesus was saying, to which Jesus expresses surprise that this man, who claims to be a teacher of the people, could not understand even some basic spiritual truths. "You," scoffs Jesus, "are Israel's teacher... and [yet you do not] understand these things?" (John 3: 8-10). If you can believe the accounts in the Bible, Jesus even killed a tree just because it didn't have any fruit for him when he walked by it one early morning (Matthew 21:18-20)

And it wasn't just that Jesus was an impatient anti-authoritarian who did not think twice about thumbing his nose at the local authorities. If this was all, we could call Jesus a punk and leave it at that. However, Jesus was, in fact, an actual dyed in the wool revolutionary. In his own words, or as close to his own words as we have left, he had come to set the prisoners and the oppressed free, and had come to bring "good news" to poor. The "good news" was presumably the end of their poverty and oppression, for what could be better news than that to a poor person? In John 4, Jesus quotes from Isaiah when he says...

The Spirit of the Lord is on me, because he has anointed me to proclaim good news to the poor. He has sent me to proclaim freedom for the prisoners and recovery of sight for the blind[folded], to set the oppressed free.... Luke 4: 18.

In the above passage, Jesus clearly presents himself as a revolutionary leader working for the spiritual, political, and economic emancipation of the people. These were no idle claims. Despite his annoyed dismissals of the danger, Jesus knew exactly what he was doing and that his revolutionary activity put him in danger. From early on, he kept boundaries and didn't entrust his safety to those he did not trust (John 2: 23-25). He revealed himself only to his closest and most trusted friends, and told them explicitly "not to tell anyone who he was" (Mathew 16: 20). He was wary about the amount of attention he was drawing, and when he started to draw too much, he left an area (John 4: 1-3) so things could quiet down. It was even necessary for him to go into hiding at certain points (John 11: 54). Even his apostles knew there was a danger, warning Jesus that it was dangerous to offend the elites (Mathew 15: 12).

And there was danger. According to the Bible, Jesus was a populist revolutionary who was so charismatic and effective that despite his initial attempts to fly under the radar, he become popular nevertheless. Jesus was making believers fast, even outside his own Jewish grouping (John 4: 39-41). "News about him spread quickly over the whole region of Galilee (Mark 1:28). The people travelled for miles to see him (Mark 1: 45). He was followed everywhere he went (Mark 3: 7-8). "They gathered in such large numbers that there was no room left, not even outside the door, and he preached the word to them" (Mark 2: 1-2). They were "amazed" (Mathew 22: 22) and "astonished" (Mathew 22: 33). Curiously, he was even converting Roman centurions (Mathew 8: 5-13) and members of the ruling elite, though they were often too attached to their power and privilege to publicly show their support (John 12: 42-43). He became so popular that, at a certain point, he "could no longer enter a town openly but stayed outside in lonely places." (Mark 1: 45).

Near his end, the people, and the elites, recognized him as a revolutionary leader. At a certain point he returns to Jerusalem and when he does, the people 
throw down the ancient Mediterranean version of a red carpet, branches and leaves cut from trees, (Mathew 21: 8) and declare him their king and saviour (John 12: 12-15; Mathew 21: 1-11) while their children sing "Hosanna" (Mathew 21: 15). Jesus, in a symbolic act that undermines hierarchy, power, and privilege, and befitting the populist proletarian revolutionary that he was, takes it all in while riding a donkey (John, 12: 14). And lest there be any doubt that Jesus is a revolutionary, consider that when he enters the town he goes straight to the temple and, enraged by the sacrilegious commercial activity, overturns "the tables of the money changers and the benches of those selling doves," calls everybody within a thief (Mathew 21: 12-13), and drives out the buyers and the sellers! Then, once he has control of the temple, he infuriates the local elites by healing and teaching freely with neither authority nor accreditation (Mathew 21: 14-17).

Not surprisingly, all this revolutionary activity pisses off the Powers that Be and the next day "the chief priests and the elders of the people" (Mathew 21: 23) storm into the temple and demand Jesus explain himself (Mathew 21: 23). Jesus asks them a simple question (Mathew 21: 24-27) and then dismisses them as ignorant when they cannot come up with an answer (Mathew 21: 27).

And it doesn't stop at the temple. In the days that follow he calls the elites blind liars, deceivers, and vipers (Mathew 23: 33-34). He says they are shallow hypocrites, pretty on the outside but diseased and rotten within (Mathew 23: 2326). He accuses them of pompous and self-aggrandizing displays (Mathew 23: 57), says they do not practice what they preach (Mathew 23: 2), says that they prevent people from connecting (Mathew 23: 13), and accuses them of never being connected for themselves (Mathew 23: 13). He even calls them anti-Christ (consciousness) by saying they undermine people's spirituality, and twist and corrupt what they touch (Mathew 23: 15).

Astonishing.

Here is Jesus, a mere carpenter from working-class Nazareth (Mark 1: 9), totally ignoring rules, laws, and convention, spitting in the face of elite authority, and being recognized by the common folk as Messiah and king. As you can imagine, this did not sit with well the ruling class of his day. Jesus was poking the belly of the Beast, so to speak, undermining them in front of the masses, and they did not like that one bit. Jesus was, in fact, a clear threat to their power and the status quo (John 12: 19), and they did not take the threat lying down. They wanted to have him arrested, but couldn't because they were "afraid of the crowd" (Mathew 21: 45-46) whom they knew would defend him. Even when the elites got over their fear and tried to have him arrested, they had trouble. Not only did they risk a riot if they tried to take him (Mathew 26: 3-5), but they lost their guards to the movement. When the "chief priests and the Pharisees sent temple guards to arrest him," (John 7: 32), the guards came back converted, or at least sympathetic (John 7: 45-46), and they refused to bring him in. Flabbergasted at the fact that their own police would not follow orders, they cry out, "You mean he has deceived you also?" (John 7: 47).

Of course, just because they couldn't have him arrested did not mean they stopped trying to deal with him. They tried to undermine him at every turn. They tried to entrap him, for example, by getting him to admit to tax evasion (Mathew 
22: 15-22), or to illegally healing on the Sabbath (Mathew 12: 9-10)). They painted him as a sinner and a demon and called him Beelzebub behind his back (Mathew 12: 24). They accused him of "being his own witness" (i.e. bragging about his qualification) (John 8: 12-14), questioned his youth and inexperience (John 8: 57), shamed him for coming from the 'hood that was Galilee (John 7: 52), tried to get people to rat him out, excommunicated those who acknowledged him as Messiah (John 9: 22), and generally got themselves so riled up that they were at times ready to stone him on the spot (John 8: 59).

In one particularly electrifying incident, the elites tried to entrap him by bringing an adulterous woman to Jesus whom, according to the laws of the land, should be brutally stoned to death. Testing Jesus to see if he'd follow the law they said, "Teacher, this woman was caught in the act of adultery. In the Law Moses commanded us to stone such women. Now what do you say?" Brilliantly, disrespectfully, and with insolent disregard, Jesus put his head down, drew circles in the dirt, and actively ignored them. Refusing to be put off, the elites keep badgering him. Finally, perhaps knowing they wouldn't leave him alone until he said something, Jesus looks up and, with the perfunctory grace that only a master can affect, fires off an earth-shattering meme that rattles the collective consciousness of this planet even down to this day. Looking up from his doodles, Christ simply says, "Let any one of you who is without sin be the first to throw a stone," after which he looked back down and ignored them once again (John 8: 19). What could the elites say? In a single perfunctory retort, Jesus masterfully exposed them as hypocrites and skilfully stripped them of their power. Left with nothing but their own guilt and shame, they turned and walked away.

Notably, Jesus's disrespect for authority is contagious, making even the blind steadfast and defiant. In one event, we find the Pharisees trying to dig up dirt on Jesus by questioning a formerly blind man whom Jesus had allegedly healed. They badger the man and his parents trying to get them to say something that would incriminate Jesus, but the man simply says that Jesus "is a prophet" (John 9: 17). Not accepting this, the Pharisees interrogate him, suggesting that maybe he wasn't blind after all, but his parents confirm that he was (John 9: 20-21). Getting no traction, the elites admonish the man to "tell the truth" because everybody knows that Jesus "is a sinner" (John 9: 24), but the blind man doesn't fall for it (John 9: 25) and in fact ends up getting insulted (John 9: 26-28) and kicked (John 9: 34) because he owns their attempted interrogation (John 9: 13-33)

For the elites, it was a bad scene, indeed. Not only was Jesus undermining their authority, but his attitude and disrespect were contagious. They couldn't let it go and they knew it. At a high council meeting of the Sanhedrin, ${ }^{6}$ the ruling elites of the city of Judea worried that they were rapidly losing control of the situation. For them, it was a political issue, not a spiritual one. They saw their political and economic power under threat. Note, however, their particular worry was not so

\footnotetext{
${ }^{6}$ Sanhedrin is the Hebrew word for city council. The Sanhedrin were a patriarchal group of twenty-one men with "full authority" over the people of the city. They made all the rules which the people, according to ancient scripture, were commanded by God to obey.
} 
much Jesus himself as their overlords in Rome. The elites worried that if Jesus got too popular, if he became too much of a threat to their local colonial power, if the people did try to install him as an authority in the region, the colonizing over-lords would send Roman soldiers to take back control and throw them out of power. This concern is stated quite plainly: "Here is a man performing many signs," noted the elite priests of the day. "If we let him go on like this, everyone will believe in him, and then the Romans will come and take away both our temple and our nations" (John 11: 45-48).

They had to contain the threat. They struggled, as already noted, to arrest and entrap him. Finally, one particular member of the elite, a high priest by the name of Caiaphas, came up with a brilliant solution. He does not mince words, or hide his intent. He wants Jesus dead. "It is better," he says, "for [this]... one man [to] die..." than that "the whole nation perish" (John 11: 50). ${ }^{7}$ Caiaphas knows if they do not act it is only a matter of time before the Romans military steps in. Convinced by Caiaphas of the imminent threat, the elites immediately began plotting to have Jesus assassinated (John 11: 53). Caiaphas takes the lead on this. Knowing full well that simply arresting and murdering Christ would be too difficult/explosive, he initiates an unusual and darkly brilliant propaganda campaign designed to open a psychological space that will allow them to arrest and assassinate the people's leader. Instead of condemning Jesus like his colleagues were doing, Caiaphas came out on his side, or so it seemed. Caiaphas admits that Christ is special and a prophet, but in an evil twist says God had sent Jesus to die.

“...as high priest that year he prophesied that Jesus would die for the Jewish nation, and not only for that nation but also for the scattered children of God, to bring them together and make them one" (John 11: 51-52).

The message sent by Caiaphas was clear. Jesus was going to die, but that was a thing that should be welcomed because it would bring unity to the scattered children and save the Jewish nation. It wasn't a lie. If the Jewish elites could get rid of Christ, their authority over Jerusalem would continue. Jesus would die for the Jewish nation, just not in the way you assumed when you glossed over the story. It was dark and devious take-down. Knowing full well that the people would simply ignore him if he called Jesus down, or revolt if he had Jesus arrested and executed, he acknowledges what the people already believe, which is that Jesus is the Messiah. After he's convinced the people he's a trustworthy source that sees "the truth," he manipulates their thinking and sets in them the expectation that God has sent Jesus to die for their sins. In this way, Caiaphas opens a space in their minds that allows him and "the family," as I like to say (Sosteric 2016), to get

\footnotetext{
${ }_{7}^{7}$ In some circles, Jews are blamed for the assassination of Jesus. This reading of the Bible, however, is only possible if one has not read the Bible, or if one takes quotes like John 11:50 out of context. When one reads the entire gospel, it is very clear that Jesus does not threaten the Jewish people. If anything, he's converting gentiles to the cause. Jesus was in fact an admitted threat to the economic and political elites of the time, and not only the Jewish elites, as we'll see.
} 
away with murder. Under the influence of this remarkable propaganda campaign, when Jesus is finally arrested, tried, and executed, the people, instead of rising up to defend their Savior as you would expect given his popularity amongst them, simply stand by and watch him die. Why should they interfere? Why should they revolt? The people, the masses, believe what we might want to call the Caiaphas Lie, ${ }^{8}$ later formalized in Catholic "Jesus died for your sins" dogma, that God had produced a "passion play," with Jesus as a willing sacrificial victim who died specifically to save your foul soul.

\section{Mock Trials}

Not surprising, perhaps, the elites were successful in their bid. With propaganda seeded in mind, the elites easily have Jesus arrested (John 18), after which they put him through some mock trials. First, they bring him before Annas, the father-in-law of Caiaphas. Annas questions Jesus (John 18:19) and ends up slapping him in the face because he can't brook Jesus' insolence (John 18: 20-23) and defiance (John 18: 23). Frustrated, Annas sends him "bound to Caiaphas" (John 18: 24) who then takes Jesus directly to the Roman overlord Pilate (John 18: 29). Pilate asks the leaders what the charges are, but they cannot provide any, saying only that "If he were not a criminal...we would not have handed him over to you" (John 18: 30). Seeing that the local elites have nothing on Jesus, Pilate, dismisses the nonsense, saying, "Take him yourselves and judge him by your own law" (John 18: 31). But the local elites don't want that. They want Jesus to die (John 18: 31), but they know if they do it, it will burst the ideological bubble that surrounds the Caiaphas Lie. To preserve the "dying for your sins delusion," they need Pilate, a Roman, to kill Jesus; so, they keep pushing and pushing. Finally, Pilate gives in to their pressure and takes Christ inside for more questioning. ${ }^{9}$ Scrambling for something concrete upon which to justify charges, he asks Jesus directly, "Are you the king of the Jews" (John 18: 33)?

“Is that your own idea, or did others talk to you about me?” Jesus asks (John 18: 34).

\footnotetext{
${ }^{8}$ https://spiritwiki.lightningpath.org/Caiaphas_Lie.

${ }^{9}$ The next few sentences recount a "scene" where the only two people in the room were Pilate and Jesus. We really don't know what happened in that room, and we never will. We don't know whether the gospel is offering a total fabrication, an account based on some form of research, or just a best guess as to what really happened in the room. Personally, I think it may be an account based on some form of research. I can see details of the conversation getting out. Pilate seems to see the whole affair like as a triviality and nothing more. He almost certainly would have talked about what happened to his closest associates, they would have almost certainly talked about it to others, and so on. This information could have eventually got out into the streets where somebody interested in the whole thing could have written it all down. Of course, even if this is true, how accurate the recounting would be after passing through so many mouths, and whether or not the scribe (in this case "John") added his or her own particular spin, would be an open question. The veracity of the scene here is open to question. But the point is, even though it was a private audience, it is possible we could have learned the details.
} 
Pilate admits, he does not know anything about this situation (John 18:35), so Jesus says no I'm not a King because if he were, my "servants would fight to prevent my arrest by the Jewish leaders" (John 18:36: emphasis added). I'm just here to "testify to the truth," Jesus says. "Everyone on the side of truth listens to me" (John 18: 37), to which Pilate, perhaps thinking that Jesus is no threat at all, scoffs and says "What is truth?" (John 18: 38).

Finding no basis for charge, Pilate once again confronts the local elites saying, "I find no basis for a charge" (John 18: 38)." He goes further and gives the local leaders and out. He says, "it is your custom to release a prisoner at the time of Passover;" so, do you "want me to release" him? (John 18: 39). But, the elites, who are so threatened by Jesus that they must see him dead, say they would rather have another Jew, Barabbas, an actual revolutionary who participated in an uprising, released (John 18: 40).

At this point, Pilate, who doesn't believe Jesus is guilty of anything, sends Jesus to the back to be flogged and publicly shamed (John 19: 1-2). After his flogging, Pilate brings him back out and once again tries to release him: “...I find no basis for a charge against him" (John 19: 4). But the elites want him dead. Over the broken and beaten body of Jesus they yell, "Crucify! Crucify!" (John 19: 6), yet in the face of this, Pilate still refuses (John 19: 6) and repeatedly tries to release Jesus (John 19: 12). But pushing, pushing, pushing, the leaders will have none of that. Finally, the local elites find his Achilles heel, his fear of Caesar. They threaten Pilate, saying that letting Jesus go would reveal Pilate as a traitor to Caesar (John 19: 12). His hand forced, Pilate capitulates. He brings the tortured body of Jesus out one last time and then hands him over for execution (John 19: 13-16).

\section{Fomenting Revolution}

At this point, we need to take a step back. Is this interpretation I am offering correct? Was Jesus truly a revolutionary, populist leader challenging the elite status quo? It does appear to be that way. Consider his celebrity status, people's readiness to anoint him King, his explicitly stated goal of emancipating the oppressed, the elite's recognition of the threat, Caiaphas's sophisticated propaganda campaign, and their insistence that he be executed. What is more, Jesus himself was aware of his mission and the threat it posed to the system. He knew his teachings put him in danger, and he took precautions from the start. At a certain point, he even knew he was going to be assassinated. He didn't like that idea, but he knew there was nothing he could do to stop it. He also knew, with full consciousness, that his murder would make him a revolutionary martyr. He says as much in John 12 when, comparing himself to a stalk of wheat, he says that "unless a kernel of wheat falls to the ground and dies, it remains only a single seed. But if it dies, it produces many seeds" (John 12: 19-24). In this passage, Christ is saying that when he dies, the kernel of his teachings will create many seeds which will then spread throughout the world. 
He was right. This is exactly what happened. He died as a martyr, and the seed of his teachings immediately started to spread. It spread because the apostles and other believers "never stopped teaching and proclaiming the good news" (Acts 5: 43). Despite the word of mouth nature of the times, it spread fast, with an increase of disciples (Acts 6:7), sometimes as many as three thousand (Acts 2: 41) or even five thousand (Acts 4:4) at a time, and not only amongst the target audience Jews, but amongst the Gentiles as well (Acts 10: 44-45). We see the conversion of Roman centurions (Acts 10: 23-26), traditional priests (Acts 6:7), foreign state officials (Acts 8: 32-36), and even top-level elites (Saul's Conversion Acts 9). There is conversion "through the whole region" (Acts 13: 49). In Iconium, Lystra, Derbe, Syria, (Acts 14), Philippi (Acts 16), Thessalonica, Berea, Athens (Acts 17), Corinth, (Acts 18), and Ephesus (Acts 19), Christ's martyrdom created a revolutionary steamroller plowing through the region.

As you might expect, confronted with the failure of their assassination, and facing a growing revolutionary threat, the elites pushed back. It was an apostolic gong show worthy of Monty Python treatment. The elites arrest the apostles but release them for lack of evidence (Acts 4: 13-17). They order them to cease and desist, but the apostles refuse to stop teaching (Acts 4: 18-20). They are arrested again, "carefully," (Acts 5: 17-18) because the "captain of the guards" was afraid of being stoned by their supporters (Acts 5: 25-36), but they escape, only to be arrested again (Acts 5: 25-29). The Sanhedrin ask the apostles why they ignored their orders to stop teaching (Acts 5: 28), and the apostles tell them they've no respect for their authority, but "must obey God rather than human beings!" (Acts 5: 29-32). Enraged, the Sanhedrin considered murder (Acts 5: 33), but eventually settle on flogging (Acts 5: 40). The apostles consider the flogging a badge of spiritual honour and joyfully go back to their teaching (Acts 5: 41-42). ${ }^{10}$

Of course, it doesn't always end so happily for the apostles, or their followers. Sometimes, when they showed too much disrespect (Acts 7), they were brutally murdered (Acts 7: 54-60). Acts 7 tells the story of the apostle Stephen who, when brought before the Sanhedrin on trumped-up blasphemy charges (Acts 6: 8-12), enrages the Sanhedrin priests to the point where they have him violently stoned to death. They lay out the charges but instead of responding to them, he goes into a long retelling of the story of Moses (Acts 7: 2-50) which ends with him namecalling the Sanhedrin (Acts 7: 51-53). Furious to the point of bruxism (Acts 7:54), he insults them even further by pointing out the strength of his own connection while passively aggressively attacking their lack (Acts, 7: 54-56). "Oh look," he says pointing to the sky, "I see Jesus and God." The Sanhedrin snap! Covering "their ears" they scream "at the top of their voices," rush him, drag him out into the streets, and stone him till he's dead (Acts 7: 54-60).

As we can see, the struggle was real, revolutionary, and vicious. It led to military pogroms (Acts 8: 1-4), mass deportation, and the scattering of "the faithful" far and wide (Acts 11: 18). It was pervasive persecution (Acts 20: 22-24) aimed at stamping out the threat.

${ }^{10}$ This is the story that Mel Gibson should have told. 


\section{Detailed Nature of the Threat}

At this point, it seems reasonable to conclude there was something revolutionary going on at the time. Something had got the people so worked up that they were converting in droves. Something had got the elites so uptight that they had Jesus assassinated, were murdering his apostles, and were engaged in mass deportation and persecution. The question at this point is, what was the nature of the threat? I believe the threat was three-pronged. There was a political threat, an economic threat, and a theological threat.

\section{Political Threat}

For sure we know there was a political threat. Everything excised from the Gospels and Acts in this paper so far points to the reality of this threat. Jesus neither liked nor respected elites. He repeatedly insulted them, called them out, and dismissed their authority, all the while calling for freedom and revolution. His followers were ready to oust the local elites and proclaim him king and they had to assassinate him to terminate that threat. Assassination did not end the threat, however. It only made him a martyr and probably encouraged a faster spread through the activity of committed apostles who become involved in revolutionary activity as well. We also know that the apostles were not passive lambs either. At one point we find Paul telling the Corinthians to quit acting like fools, quit putting up with exploitation, resist (2 Corinthians 11: 19-20), and rise up and proclaim the revolutionary good news despite oppression and suppression, as he had done (2 Corinthians: 23-29). And the Corinthians were not the only ones he was encouraging towards progressive political positions. Elsewhere, Paul reminds the Galatians of the importance of freedom from the "yoke of slavery," and advises they not allow themselves to be enslaved once again (Galatians 5: 1). Paul's was a revolutionary call made more focused and dangerous because he was erasing hierarchy and division, and, in a perverse fulfillment of Caiaphas's twisted prophecy, uniting the people as one. "There is neither Jew nor Gentile, neither slave nor free, nor is there male and female, for you are all one in Christ Jesus" (Galatians 3: 28). Calls for unity like this are always fundamentally revolutionary because they always move past the elites "divide and rule strategies, which make exploitation and oppression possible.

\section{Economic Threat}

The threats Jesus and his apostles represented were not just political. At root, politics is always about economics, and there is evidence to suggest that there were socialist/communist undertones to the Christian revolution underway in the region. We already know Jesus didn't think much of the rich or their abilities, suggesting 
it was simply impossible for them to connect (Mathew 19:24). ${ }^{11}$ Beyond that, he made clear statements against the accumulation of wealth. ${ }^{12}$ In Mathew 19, when a rich man asks Jesus, "What good thing must I do to get eternal life?" (Mathew 19: 16), Jesus says point-blank, "If you want to be perfect, go, sell your possessions and give to the poor....Then come, follow me." (Mathew 19: 21).

This communistic rejection of personal possessions was not confined to Jesus himself. His apostles picked up on it as well. Consider the following as a clear indication of the communal/communist nature of the early Christian community.

All the believers were one in heart and mind. No one claimed that any of their possessions was their own, but they shared everything they had... And God's grace was so powerfully at work in them all that there were no needy persons among them. For from time to time those who owned land or houses sold them, brought the money from the sales and put it at the apostles' feet, and it was distributed to anyone who had need (Acts 4: 32-37).

Selling your home and giving the proceeds away for redistribution? It doesn't get any more communistic than that. The early Christians took the communism quite seriously. Consider the story of Ananias, a Christian convert who sold his property but kept some money back for himself.

Now a man named Ananias, together with his wife Sapphira, also sold a piece of property. With his wife's full knowledge he kept back part of the money for himself, but brought the rest and put it at the apostles' feet. Then Peter said, "Ananias, how is it that Satan has so filled your heart that you have lied to the Holy Spirit and have kept for yourself some of the money you received for the land? Didn't it belong to you before it was sold? And after it was sold, wasn't the money at your disposal? What made you think of doing such a thing? You have not lied just to human beings but to God." When Ananias heard this, he fell down and died. And great fear seized all who heard what had happened. Then some young men came forward, wrapped up his body, and carried him out and buried him." About three hours later his wife came in, not knowing what had happened. Peter asked her, "Tell me, is this the price you and Ananias got for the land?" "Yes," she said, "that is the price." Peter said to her, "How could you conspire to test the Spirit of the Lord? Listen! The feet of the men who buried your husband are at the door, and they will carry you out also." At that moment she fell down at his feet and died. Then the young men came in and, finding her dead, carried her out and buried her beside her husband. Great fear seized the whole church and all who heard about these events (Acts 5:1-11).

Ananias kept the money for himself. When the community found out, he was challenged by the apostle Paul. When the seriously misaligned nature of his selfish actions was discovered and brought to his attention, first he, and then his complicit wife, dropped dead. Those are pretty serious consequences for stealing a little cash

\footnotetext{
${ }^{11}$ It is, of course, impossible to get a camel through the eye of a needle.

${ }^{12}$ For my take on "accumulation" see my Rocket Scientists' Guide to Money and the Economy Sosteric (2016)
} 
from the community; I think you'll agree. Perhaps it is just a moral tale, and Ananias and his poor wife didn't really drop dead, but even so, the story clearly shows how serious the early Christians took their redistributive socialism.

Speaking of redistribution, there is obvious talk about income redistribution in the Bible. In 2 Corinthians 8, Paul writes a letter to the Corinthians and in that letter appeals to them to be as generous as the Macedonians when they give over their excess production for redistribution. Paul's stated goal is general equality. He says, and I paraphrase, "You folks got lots, they got a little, and so now it is your time to help them. Then, one day, they will have a lot and you will have a little, and in their turn they will help you."

The point, as Paul repeatedly says, is simple equality.

Our desire is not that others might be relieved while you are hard pressed, but that there might be equality. At the present time your plenty will supply what they need, so that in turn their plenty will supply what you need. ${ }^{13}$ The goal is equality, as it is written: "The one who gathered much did not have too much, and the one who gathered little did not have too little" (2 Corinthians 8: 13-15).

We redistribute, Paul says, so we can achieve general equality.

The socialist goal of Paul is obvious, as is his usage of ancient Jewish scripture to justify it. And note, this is not about giving a few pennies on Sunday; this is about serious redistribution. This is about looking out for all people. It is not about being lazy and parasitical, says Paul, it is about working hard, helping the poor and the weak, and making sure everybody has enough. They rejected, I have to say, consumerism and indulgence and embraced compassion and service to others (Galatians 5: 13; Philippians 2: 3-4).

I have not coveted anyone's silver or gold or clothing. You yourselves know that these hands of mine have supplied my own needs and the needs of my companions. In everything I did, I showed you that by this kind of hard work we must help the weak, remembering the words the Lord Jesus himself said: 'It is more blessed to give than to receive' (Acts 20: 32-35).

\section{Theological Threat}

When you combine the clear socialism with the anti-authoritarian politics, you begin to get a different picture of Jesus, the apostles, and the Bible story. I think there is enough evidence left in the Christian bible to suggest that the early movement represented a communist/socialist threat. But it was more than that. Early Christianity also represented a theological threat to Jewish monotheism, to the notion that there was some authoritative "God" up in the sky. Jesus and his apostles presented a different, perhaps more nuanced, view of God. Jesus and his

\footnotetext{
${ }^{13}$ This sound frighteningly close to what communist Karl Marx said about equality and redistribution, "From each according to his ability, to each according to his need."
} 
apostles taught a very "revolutionary" truth, which is not really revolutionary at all, given it is a common theme in this world's spiritual traditions (Bhattacharyya 2006, Jantzen 1995, Ichazo 1976, Underhill 2002), which was that we were all sparks of divine Consciousness, that inside us we are all equally God incarnated in a physical body.

Jesus himself is quite clear about this. At a certain point, Jesus is about to be stoned for blasphemy, because as the elite priests are saying, he is, "a mere man," claiming "to be God" (John 10:33). Even though he's about to be stoned to death, Jesus does not deny that he says this. Instead, he points to Jewish scripture, specifically Psalm 82, and says we are all god.

"You are gods; and all of you are children of the Most High.” (Psalm 82:6)

This isn't the only place where Jesus erases the distinction between God and humans. In Mathew 18:17-18 Jesus again suggests we are all equally divine. Later, in the "letters" section of the Bible, this theology is repeated by Paul in 1 Corinthians 6:19 where he says "Know ye not that ye are the temple of God, and that the Spirit of God dwelleth in you?" He says it again in Colossians 3: 11: "Christ is all, and is in all." Notably, this isn't something that has been lost to subsequent generations of Christians. Meister Eckhart carries the idea forward into the European Middle Ages when he says.

The seed of God is in us. Given an intelligent and hardworking farmer, it will thrive and grow up to be God, whose seed it is; and accordingly, its fruits will be God-nature. Pear seeds grow into pear trees, nut seeds into nut trees, and God's seed into God. God expects but one thing of you, and that is that you should come out of yourself, in so far as you are a created being and let God be God in you. Meister Eckhart.

\section{Discussion}

Don't listen to authority. Ignore meaningless tradition. Don't follow their rules. Give your possessions away. Redistribute wealth. Embrace your divinity! You are God. We are god's. God is in us. God becomes us. Gender, ethnicity, nationality don't matter. We are all one. We all deserve equality. We should help the weak, not prey on them. Is this remarkably progressive message really contained in the Bible? And if so, what are we to make of this?

As to the question whether the message is contained in the bible; arguably, it is. It is right there in black and white for all the world to see. As for what to make of this, as a recovering Catholic, I'm wondering, why I was never told this as a child, and I'm a bit confused by the teachings of the Church. Even though I spent the first decade of my life immersed in the Church and its teachings, dutifully attending Sunday Mass every week of every year, I had no idea about this. The priests never said any of this about Jesus or his apostles. They never told me he was a revolutionary, that he taught collective divinity, or that his politics were far left. I realize now they didn't tell me the truth; they told me the Caiaphas Lie. They told me he was a passive Sheppard who died on the cross for my sins. Why 
would the Catholic Church tell the Caiaphas Lie? Why were they covering up the sins of the High Priests who had Jesus executed?

As a former Catholic, I have a hard time understanding the Church and its perspectives, but as a sociologist, I have a clear view of what's going on. As a sociologist, it all makes perfect sense. It makes sense why Jesus was so popular. It makes sense why the people proclaimed him king. It makes sense why Caiaphas told that lie. It makes sense why he was assassinated, and why this martyred him. It makes sense why his message spread. It makes sense why the Roman's persecuted and deported early Christians. It also makes sense why the Church, throughout the middle ages, repeatedly worked to circumvent the progressivism and social "activation" that emerged from an authentic practice of Christ's authentic spiritual teaching by forcing mystics, especially women mystics, into monasteries, editing their teachings, threatening them with the violence of the inquisition, and otherwise containing the progressive impulse (Bruneau 1998). It makes sense why the Church "fathers," the elites who started the Church, handpicked only a sample of the writings available at the time for their official Bible, and destroyed everything else (Starr 2013: 179). It makes sense why they wouldn't let the common folk read the bible for themselves for over a thousand years (Starr 2013: 162), and why they still organize their Sunday sermon around out of context selections that allow priests to whitewash the revolutionary message. It makes sense why there is so much predatory behaviour and mental illness amongst the patriarchs of the Church (Sosteric 2019a). The Church isn't about freeing the soul. Nor is it only about opiating the people (Marx 1978) or ideological manipulation of masses (Weber 1904) though all this is certainly a part. It is equally about containing a problematic, progressive, spirituality that breeds political activation (Sosteric 2019b) which, if left unchecked, might otherwise transform the world (Sosteric 2018c). As a sociologist, I can clearly see the Church, headed by elites like Emperor Constantine, was not created to spread the word, but to contain the socialist/theological threat.

As a sociologist, the case seems clear enough, and the need for research on the question obvious. But as a sociologist, another bothersome issue arises. The bible has been easily available for decades. In the last ten years, especially so in the last decade where multiple versions are easily accessible online. Progressive sociologists have been interested in social change and social evolution since the beginning. Clearly, Christ was a progressive. So why have sociologists never spoken about this charismatic, progressive, and highly successful figure in terms that reflect the story in the Bible? Why such derision? That doesn't seem right. The answer, I think, is simply that despite pretensions to actually know something about Christian religion, most sociologists who claim to know about Christian spirituality haven't actually read the bible. Consequently, their understanding of Christianity is based on what the Church says, and what the Church says is not the full story. Take Marx as an example. Marx said that religion was "the sigh of the oppressed creature, the heart of a heartless world, and the soul of soulless condition. The opium of the people" (Marx 1970). Anybody who actually reads the gospels would have a hard time making that statement. Engels is a bit more accurate when he says the following: 
The history of early Christianity has notable points of resemblance with the modern working-class movement. Like the latter, Christianity was originally a movement of oppressed people: it first appeared as the religion of slaves and emancipated slaves, of poor people deprived of all rights, of peoples subjugated or dispersed by Rome. Both Christianity and the workers' socialism preach forthcoming salvation from bondage and misery; Christianity places this salvation in a life beyond, after death, in heaven; socialism places it in this world, in a transformation of society. And in spite of all persecution, nay, even spurred on by it, they forge victoriously, irresistibly ahead. Three hundred years after its appearance Christianity was the recognized state religion in the Roman World Empire. (Engels 1894)

But even he shows signs of not having read the Bible carefully. To be sure, early Christianity was socialist, but it did not place "salvation in a life beyond, after death, in heaven." There was a practical, real-time concern to improve material conditions by eschewing accumulation and redistributing income. It was only later, when the elites took control, that this revolutionary message was occluded. Religion is not the "opium of the people," a "tool of the ruling class," a "general theory of this alienated world," (Molyneux 2008), even a "response to human alienation" (Molyneux 2008). Religion, at least the Christian variety, is an institution developed to sanitize and suppress the progressive human spirituality of Jesus Christ, and others (Harvey 2001). This, in my view, more accurate statement of the role of religion moves us past the flawed Marxian view, not to mention the banal inanity of folks like Richard Dawkins (2006) and presents a more nuanced view of human spirituality. As a few sociologists are aware, religion is not an opiate; it is a containment strategy. It is the spearhead of an ancient and sophisticated control process (Sosteric 2017) that sanitizes (Jantzen 1995), manipulates (Sosteric 2018b) co-opts, and defuses (Bruneau 1998), an otherwise revolutionary human spirituality. Given this, it is time we, as sociologists, get past the neglectful, "parochial - concentration on ecclesiastic institutions," and take a closer, more scientific and less prejudiced look at human spirituality and its transformative (Bien 2004, Miller 2004, Hastings 2010, White 2004) and revolutionary (Sosteric 2018c) potential.

\section{References}

Berger P (1968) A Bleak Outlook Is Seen for Religion. vol. April 25. The New York Times. Berger P 1(969) The Sacred Canopy: Elements of a Sociological Theory of Religion. New York: Anchor Books.

Berger P (1999) The Descularization of the World: Resurgent Religion and World Politics. Grand Rapids MI: Eerdmans.

Bhattacharyya AK (2006) Hindu Dharma: Introduction to Scriptures and Theology. Lincoln, NE: iUnvierse.

Bien TH (2004) Quantum Change and Psychotherapy. Journal of Clinical Psychology 5: 493.

Bruce S (2002) God Is Dead: Secularization in the West. Oxford: Blackwell.

Bruneau MF (1998) Women Mystics Confront the Modern World. Albany: State University of New York Press. https://amzn.to/2L1L0m2. 
Chaves M (1994) Secularization as Declining Religious Authority. Social Forces 72(3): 749-74.

Dawkins R (2006) The God Delusion. Feb. 12. New York: Mariner Books.

Dobbelaere K (2002) Secularization: An Analysis at Three Levels. Frankfurt: Peter Lang.

Durkheim E (1965) The Elementary Forms of Religious Life. New York: Free Press.

Engels F (1894) On the History of Early Christianity. Marxists Internet Archive. https:// bit.ly/34wY2OK.

Harvey A (2001) Teachings of the Hindu Mystics. Kindle. Boston: Shambhala Publications. https://amzn.to/2WQoduv.

Hastings A (2010) William James, Conversion and Rapid, Radical Transformation. Journal of Consciousness Studies 17(11-12): 116-20.

Ichazo O (1976) The Human Process of Enlightenment and Freedom. New York: Arica Institute.

Jantzen GM (1995) Power, Gender, and Christian Mysticism. New York: Cambridge University Press. https://amzn.to/2U490E9.

Marx K (1970) A Contribution to the Critique of Hegel's Philosophy of Right. Cambridge: Cambridge University Press.

Marx K (1978) The German Ideology. In The Marx-Engels Reader, edited by R. Tucker. New York: Norton.

Miller WR (2004) The Phenomenon of Quantum Change. Journal of Clinical Psychology 60(5): 453-60. https://doi.org/10.1002/jclp.20000.

Molyneux J (2008) More than Opium: Marxism and Religion - International Socialism. International Socialism, 2008. http://isj.org.uk/more-than-opium-marxism-and-religi on/.

"New International Version (NIV) - Version Information - BibleGateway.Com" (2019) 2019. https://www.biblegateway.com/versions/New-International-Version-NIV-Bib le/.

Sosteric M (2014) A Sociology of Tarot. Canadian Journal of Sociology 39(3).

Sosteric M (2016) Rocket Scientists' Guide to Money and the Economy: Accumulation and Debt. St Albert, Alberta: Lightning Path Press.

Sosteric M (2017) The Sociology of Mysticism. ISA ESymposium for Sociology July.

Sosteric M (2018a) "Everybody Has a Connection Experience: Prevalence, Confusions, Interference, and Redefinition." Spirituality Studies 4 (2). https://bit.ly/2GubUBA.

Sosteric M (2018b) From Zoroaster to Star Wars, Jesus to Marx: The Science and Technology of Mass Human Behaviour. https://www.academia.edu/34504691.

Sosteric M (2018c) "Mystical Experience and Global Revolution." Athens Journal of Social Sciences 5(3): 235-55.

Sosteric M (2018d) Star Wars Is a Religion That Primes Us for War and Violence. The Conversation. https://bit.ly/33z19Xc.

Sosteric M (2019a) A River of Power Runs Through Us. Culturally Modified. https://cul turallymodified.org/.

Sosteric M (2019b) Rocket Scientists' Guide to Authentic Spirituality. St. Albert, Alberta: Lightning Path Press. https://bit.ly/33xBe28.

Sosteric M, Ratkovic G (2018) What Does It Mean to Be Human: Abraham Maslow and His Hierarchies of Need. https://www.academia.edu/35635479.

Starr B (2013) Jesus Uncensored: Restoring the Authentic Jew. OmniHouse Publishing.

Underhill E (2002) Mysticism: A Study in the Nature and Development of Spiritual Consciousness. Kindle. New York: Dover Publications. https://amzn.to/2C91xNY.

Wallis R (1976) The Road to Total Freedom: A Sociological Analyysis of Scientology. London: Heinemann. 
Vol. 9, No. 1 Sosteric: Rethinking the Origins and Purpose of Religion...

Weber M (1904) The Protestant Ethic and the Spirit of Capitalism. New York: Roxbury Press.

White WL (2004) Transformational Change: A Historical Review. Journal of Clinical Psychology 60(5): 461-70. 